\title{
Personal self-development as the base of evolution of the modern legal education: theoretical and legal position
}

\author{
Raviya Faritovna Stepanenko ${ }^{11}$, Farida Ildarovna Khamidullina ${ }^{2}$, Lidiya Leonidovna \\ Sabirova $^{1}$, Alyona Vladimirovna Soldatova ${ }^{3}$, and Ilshat Radivovich Ashrafzyanov ${ }^{1}$ \\ ${ }^{1}$ Kazan (Volga Region) Federal University, Law Faculty, Kazan, Russia \\ ${ }^{2}$ Kazan (Volga Region) Federal University, Civil Law Faculty, Kazan, Russia \\ ${ }^{3}$ University of Management TISBI, Law Faculty, Kazan, Russia
}

\begin{abstract}
The objective of the research is the analysis of the problem of higher legal education in the context of uncertainty of the modern social and cultural space, processes of the widespread standardization of the educational environment, development of the strictly informational and cognitive and formatted thinking. The methodological base of the research is the universal, general scientific and specific scientific cognitive methods used by the legal science in the object-subject scope of cognition of the general theory of law. Besides, some synthetic, integrative methods of research are used that are part of the methodology of interdisciplinarity, actual for the modern socio-humanistic science. The result of the research is the grounded author's legal position of the advisability of the personal self-development of a student as well as a teacher without whom the obtaining of the qualitative higher legal education seems problematic and also the performing of the professional legal activity in the moral legal direction. The authors also prove that the formation and development of the modern legal consciousness and legal culture of the lawyer shall be based upon the universal and generally accepted ideas of the significance of personal rights and freedoms, postulated during the course of education as well as by the personal development. The novelty of the paper is this problem statement that was not expressed before by the scientists as the subject of research.
\end{abstract}

Keywords: legal education, self-development of the student, self-development of the teacher, legal culture, legal consciousness

\section{Introduction}

The processes of increase of the information volume, speed of permanent update of the technologies and also the more profound problems of globalization of the information environment taking place in the modern world make the educational system, including the legal education, react to these challenges. To solve the dynamically developing tendencies of technologization of the educational processes in the jurisprudence, this sphere of

${ }^{1}$ Corresponding author: stepanenekorf@yandex.ru 
education shall concentrate on studying the methodological problems of socialization and the spiritual development of the personality of the future lawyers. In scientific papers, this process is often missed and the accent is mostly focused on the necessity to form the practically significant competencies, skills, abilities, knowledge. Meanwhile, the formation of the worldview basis of the legal thinking, professional basis of legal consciousness and legal culture, methodologically grounded when learning the theoretical and legal subjects at the initial stages of the obtaining of the legal education shall give the significant role to the aspects of upbringing and self-education of the personal qualities of the lawyer in prospect.

When realizing the educational function of the fundamental jurisprudence and teaching the initial and basic notions of the legal science, giving the knowledge of peculiarities, regularities and casualties in the evolution of the state and legal phenomena the representatives of the theoretical legal science communicate the actual information to the students using their own experience and professional thinking of the existing problems. With that the education as the two-side process (and more - when using the methods of interactive education) of communication objectives not only the intellectual and professional potential of the teacher but also a complex of existing legal disciplines of the student, level and quality of his personal self-development in the law field.

The potential of the personal development of the teacher as well as the student is an objectively existing biopsychological and socio-cultural phenomena without the complete revealing of which it is not possible to explain or form the required skills, knowledge and competencies of the students. The processes of the personal development and the processes of study, in particular, of the students, do not often come together but independently, existing on their own and this decreases the general efficiency of education and forms the indifference to the obtained reference knowledge of law. Therefore, the objective of the article is to analyze the possible ways of support of the personal development and professional education in their cumulative form, as they are important for the modern legal education.

\section{Methods}

The methodological base of the research is the universal, general scientific and specific scientific cognition methods used by the legal science in the object-subject scope of cognition of the general theory of law. Besides, some synthetic, integrative methods of research are used that are part of the methodology of interdisciplinarity, actual for the modern socio-humanistic science.

\section{$3 \quad$ Results and discussion}

Currently many educational technologies, used to increase the efficiency of education (for example, the problematic education, personal and practice-oriented education, project and binary education, etc.) are developed. The active and interactive methods of education are offered and used. In many countries, including Russia, the so-called "competence approach" is implemented that has to transfer from the "coaching" of the students with knowledge to the formation of their practical skills and abilities. All the abovementioned, one way or another, when used competently or moderately can promote the personal development of the students. With that nowadays the legal education misses one of its most important task, that is to form the value legal worldview without which it is impossible to understand completely the profession of the lawyer. If this task is not solved, for example, with regard to the legal education, the prerequisites of the professional deformation appear of the legal consciousness of the students that is not formed completely. Actually, the state 
when giving a professional choice to a person in the young age, just after finishing school understands that this choice is mostly not cognitive. As the sociological researchers showed that were performed among the first-year students of the Law Faculty of the Kazan (Volga Region) Federal University, about $20 \%$ of the students decided to obtain the profession of the lawyer following the strict recommendation of their parents; $20 \%$ decided to continue the dynasty of lawyers; about $15 \%$ declared they wish to obtain any higher education; about $10 \%$ wanted to get independence far from home and parents; the other could not make a definite choice of profession and postponed this question "for the future". This problem has a direct practical significance for employers.

It was in the $20^{\text {th }}$ century when the famous American businessman Henry Ford describing the poor condition of railways in the USA wrote that "a lawyer, as well as a banker, does not understand anything in his business. They suppose that the business is going ok if it does not exceed the bounds prescribed by the law. Instead of acting according to common sense and circumstances, all railways should act according to the advices of their lawyers. Now we can see that the railways are entangled in the network of paragraphs. The lawyers and financial experts, on one side, and the administrations of the states, on the other, tied hands of the heads of railways directors completely. Business cannot be managed from above, - concludes Ford bearing in mind that the lawyer has also to get to the bottom of the business he is supporting legally [1].

The problem of deformation of the professional legal consciousness of the lawyers has been raised long ago. It was specially emphasized by Engels as the consequence of labour division, specifying that "the lawyer is enthralled by his backward legal beliefs that possess him as some independent force" [2]. But the fundamental worldview (first of all the human worldview but also the scientific one) allows avoiding such negative consequences. It is especially relevant for the higher education because "in a real university education the professionally specialized knowledge is just fragments of the general and complete worldview developed in details..." [3]. It seems that such an approach evidently shall initialize the processes of personal self-development of the students as well as the teachers. It is necessary because currently, the possibility of the direct management of informational flows and dumbing-down of people using mass media became enormous and such processes shall be counteracted by means of the various forms of self-education of the student and the teacher. The latter does not seem possible without a well-grounded system of values of the higher education that will become a guide-mark in the continuous self-education and self-development [4].

Besides, it should be clear that the full development of personality is not possible without the profound support, that is, of Idea. The great Soviet teacher Sukhomlinsky paid special attention to it. He stated with regret that there was an ironic attitude to the word "idea" and "ideological content" among people. As the author wrote such people "do not know the completeness of high-principled spiritual life and this does not mean they do not know what happiness is". But owing to the idea a person obtains his personality, expresses himself in creativity, becomes the real fighter. The person is not dissolved in the idea but becomes a powerful force due to the idea spirituality" [5].

In Russia, such circumstance was well understood, in particular, by some famous legal scholars. For example, the wall of one of the lecture halls of the Kazan Federal University is still decorated with the quotation of the pre-revolution legal scholar Zagoskin that is formulated as: university prepares people "who are capable reasonably and consciously to introduce the idea of truth into life but not the casuists who can catch fish in the muddy water of the Russian laws" [6]. Nowadays such a position is getting more popular in Russia and the jurisdiction of the Supreme Court of the Russian Federation and the Constitutional Court of the Russian Federation has already moved beyond the limits of the common legal formalism. But to make this approach commonly accepted in the legal activity in general 
the teachers and legal students shall have "support" in the form of the valuable Idea for the profession as well as for their personal beliefs.

Certainly, the students learning the law science can have another support that will promote the process of their self-development, for example, the support to the high material well-being, carrier growth, social esteem and this can cause the risks of abuse of powers, abuse of law, show off, etc. [7]. However these are supports of the lower order, they will be much more destructive for the society and inefficient for their self-expression in the profession. The latter can be pointedly traced now in post-Soviet Russia. One of the authors of this article being a post-graduate and who has recently graduated from the Bachelor's and Master's degree program in the specialty "Jurisprudence" and was among the legal students can confidently state that in the conditions of the modern lack of ideological content many young people feel the significant apathy and so-called "lostness", uncertainty when choosing a profession as well as being in the "social vacuum" of the modern reality that is the lack of that support for self-development mentioned above.

To stimulate the personal development and self-development of the students the legal education shall be related to the formation of the fundamental legal worldview that includes some Idea that will be the stimulus for such development. However, to make such idea a part of the system of legal education the fundamental human theory is required. The dominated positivistic or later liberal theory of law cannot any longer explain the global modification of the social processes [8] and become ideas stimulating the personal development of, first of all, the new generations and this is recognized in the Russian as well as in the foreign science. In particular, the famous American sociologist Wallerstein issued the book "After liberalism" in 1995 that described the collapse of liberalism as the ideology-hegemon and possible future after it. He mentioned that in this regard we should have the intellectual fight for "re-interpretation of our scientific canons" [9]. The Marxist theory having a powerful ideological base in the form of the communistic ideal also could hold its positions as its worldview was imperfect and caused disillusion (despite, for example, the problem of person exploitation by the person in the modern world raised in the Marxism is still relevant [10]). Therefore the formation of such fundamental theory (at least the well-known theory) is currently quite relevant. Its development, grounding, recognition and distribution are the main task without which it will be quite difficult to solve the problem of the personal development in the legal education. Moreover, to make such theory promote the personal development of the students it should correspond to two requirements: first, it should contain a big Idea directed to the improvement of the society, and second, the profound and full analysis of the social regularities should be made around this Idea, without this analysis the Idea will be just a declaration of good intentions that will disappoint the society with time.

At the same time one should remember that the formation of understanding and comprehension of the full worldview of the students is not possible without the continuous process of improvement of the level of legal consciousness and legal culture. As it is known, education of any level shall be a symbiosis of education and upbringing. The organization of the latter in the higher educational institutions now has unfortunately some complications. The process of upbringing especially in the higher education is not paid due attention as the priority is given to the development of the methods of education to increase the competitiveness of the graduates in the labor market. Such discordance can cause negative consequences for the self-development of personality of the student as well as for the development of the society in general. The success of upbringing depends mostly upon the expected changes in the student under impact of the specially organized actions.

The said is extrapolated into the field of study of the qualitative conditions of the modern legal education to the extent that satisfies the demands of the new technological paradigm and the social relations intermediated by the law in practice. The qualitative and 
actual legal education based upon the traditions of academism as well as on the innovative models of its provision includes the preparation of the competent, high professional lawyers with analytical, logical, critical thinking, who are able to ground their own point of view using arguments [11]. Besides the significant attention shall be paid to the formation of the value worldview for the law (positive and natural), which is filled with spiritual and moral content during the educational process.

The achievement of the set goals sets several tasks for the teachers: at the highly professional and intellectual level to bring to the students the importance and the value of the obtained knowledge, skills, abilities and competencies for their successful implementation in practice in the future; to initialize the positive motivation of their behavioral models in the law enforcement activity; to form the respect to the performed official duties and responsibility for the good execution of powers, etc.

Co-evolutional processes of interaction and evolution of the educational environment impose the responsibility on the students as well as on the teachers for this activity that should bring "human profit" as the famous philosopher and legal expert F. Bacon wrote in the XVII century. "Universities teach to believe" said the author in his famous paper "Of merits and augmentation of sciences" [12]. The belief in the teacher and what he says as a profound universality of the culture of higher value order is the stem of the dialogue communication of the two main participants of the educational process. For this the personal self-development of the teacher becomes irreplaceable and important and this requires the constant self-improvement, improvement and increase of intellectual, spiritual and scientific levels. The heuristic value in this sense gives such affirmations as cognitive abilities, intentionality of law perception and feelings in the law field, self-consciousness as the report to himself about his own actions, etc., that is estimated by the student as a "qualia" (from the Latin Qualia- property, quality) of the student and cause his corresponding reaction [13]. In synergy the internal mental conditions (thinking, sense, beliefs, intellect, way of thinking) of the teacher and the student give such synergetic effect, if they "come across" in the meeting point of the process, the results of such effect initiate the procedures of the personal self-development of the dialogue figures in the sphere of the modern legal education.

In the context of the considered problematics, the provision of continuity of the legal education is important, it should be directed to the miscellaneous formation of the personality of the professional lawyer, ready and motivated for learning during the whole life, striving to communicate and improve the indicators of the own legal culture [14].

\section{Conclusion}

One of the basic components of educational and upbringing processes of the future lawyers seems to be its axiological element that performs the most important function of the foundation of the upbringing first and later a guide mark for the self-development of the students. Undoubtedly, taking into account the increased social significance of the profession the legal education shall strive for the formation of the full scientific worldview of the future specialists, that is based upon such professionally significant qualities as kindness, justice, responsibility, honesty, self-forgetfulness, philanthropy, etc. that is a quite complicated task.

With that, it seems that the fundamental and more efficient educational method is the method of a personal example. Therefore special attention shall be paid to the state of the legal culture of students as well as of teachers. Seeking the practical orientation of higher education one should remember that the teacher is a mediator not only between the students and the employer but between the students and the science, and the students and the culture. 
In this regard, the problem of self-development of the teacher gets similar relevancy and the study of this should be paid serious attention in the socio-human science.

\section{References}

1. H. Ford, My life and work (1923). Accessed on: June 25, 2021. [Online]. Available: https://archive.org/details/mylifeandwork00crowgoog/page/n238/mode/2up

2. F. Engels, Anti-Dühring (1877). Part III: Socialism. Accessed on: June 25, 2021. [Online]. Available:

https://www.marxists.org/archive/marx/works/1877/anti-duhring/ch25.htm

3. M.V. Velichko, V.A. Efimov, V.M. Zaznobin, Ekonomika innovatsionnogo razvitiya. Upravlencheskie osnovy ekonomicheskoi teorii: monografiya [Economics of innovative development. Managerial basics of economic theory: monography] (Kontseptual, Moscow, 2017)

4. Ya.V. Soldatov, M.V. Salimgareev, Edu. and Law 3, 245-250 (2018)

5. V.A. Sukhomlinsky, Pisma k synu [Letters to the son] (Conceptual, Moscow, 2017)

6. I.A. Tarkhanov, D.Kh. Valeev, Z.A. Akhmetyanova (eds.), Kazanskie yuridicheskie shkoly: evolyutsiya obrazovatelnykh i nauchnykh traditsii v sovremennoi yurisprudentsii [Kazan Legal Schools: Evolution of educational and scientific traditions in the modern jurisprudence] (Statut, Moscow, 2016)

7. R.F. Stepanenko, State and Law, 6, 13-22 (2018)

8. O.Yu. Rybakov, Nauka, tekhnologii, pravo v zhiznennom prostranstve sovremennogo cheloveka [Science, technology, law in the life space of the modern person], in V.M. Artyomov, O.Yu. Rybakov (eds.), Scientific and technological transformations in the modern society: moral and philosophical understanding and peculiarities of the legal regulation: Collection of scientific works (RG-Press, Moscow, 2019)

9. I. Wallerstein, After liberalism (The New Press, New York, 1995)

10. N. Khazoeva, A. Khaziev, E. Klyushina, G. Stepanenko, R. Stepanenko, Utopía Y Praxis Latinoamericana, 24(1), 54 (2019)

11. L.T. Bakulina, Istoriko-pravovye distsipliny v sisteme yuridicheskogo obrazovaniya [Historical and legal subjects in the system of legal education], in O.A. Kuznetsova (ed.), The sixth Perm congress of legal scholars: Russian national legal system: modern condition, tendencies and perspectives of the development. Proceedings of the international research and practice conference, 289-290 (2015)

12. F. Bakon, Sochinenie: V 2 t. T.1. [Composition: in 2 vol. Vol.1], in A. Subbotina (ed.) (Mysl, Moscow, 1977)

13. F.I. Khamidullina, Iss. Econ. and Law 11, 7-10 (2017)

14. L.L. Sabirova, Bul. Mari State Univ. 12(2-30), $72-77$ (2018) 